\title{
NUCLEAR ENERGY AND ITS CONTRIBUTION TO THE ENERGY AND CLIMATE SECURITY OF EUROPEAN UNION
}

\begin{abstract}
Nuclear power plays an important role in ensuring the security of electricity supplies in the EU. It combines ecological and economic attributes, i.e. reduces dependence on fossil fuels and helps to avoid huge amounts emissions of carbon dioxide to the atmosphere per annum. The biggest challenge for the EU's nuclear power industry is aging fleet of nuclear reactors. Therefore, if the EU wants to maintain the current potential of nuclear power, Member States must make significant investments in order to balance production capacities that will be lost due to closure of aging power plants. In the long term perspective to replace nuclear power with renewable energy would be counterproductive, because it would mean to maintain a large share of fossil fuels in the EU's energy balance.
\end{abstract}

Keywords: nuclear energy, energy - climate security, European Union.

\section{NUCLEAR POWER IN THE EUROPEAN UNION}

Nuclear energy has a significant share in the EU's energy balance, providing a high degree of energy security and helping to reduce concerns about electricity supplies security. It provides up to $26.9 \%$ of electricity production in the EU, and around $11 \%$ in the world $(2014)^{2}$. The remaining part of the electricity is generated from burning of hydrocarbons (coal, gas, oil and renewable) $)^{3}$. In April 2016 there were operating 129 nuclear reactors (with a capacity of $120 \mathrm{GW}$ ) in 14 countries of the 28 EU Member States that were producing more than a quarter of the electricity in the EU, while only in one country - France, there were 58 reactors producing almost half of the EU's nuclear power.

Nuclear Fleet developed in stages from the decade of 60ties of the XX century, but the peak was in the 80s of the twentieth century (especially in France, Belgium, Germany, Sweden, Italy, and Great Britain). The slowdown period took place in 90ties of the last century after the Chernobyl disaster in the former USSR (1986), causing a decrease of nuclear energy popularity ${ }^{4}$. Since then, the installed capacity of nuclear power remains relatively

\footnotetext{
${ }^{1}$ Dr hab. Tomasz Młynarski, prof UJ (Tomasz Młynarski - Associate Professor at Jagiellonian University).

${ }^{2}$ EU energy in figures, Statistical Pocketbook 2015, s. 13, 16, 36, 90; Nuclear energy statistics, Eurostat 2016, http://ec.europa.eu/eurostat/statistics-explained/index.php/Nuclear_energy_statistics (access: 2.05.2016)

${ }^{3}$ Other sources of electricity in the EU are fossil fuels like coal (26.7\%), gas (16.6\%), renewable $(27.1 \%)$, petroleum $(1.2 \%)$, and other non-renewable $(2.5 \%)$.

${ }^{4}$ M. Schneider, A. Froggatt, The World Nuclear Industry Status Report 2014, Paris, London, Washington, D.C., July 2014, s. 119-120.
} 
stable. Reactors are located mainly in Western Europe (in eight countries of the EU-15). In 2014, there were operating 112 units and two reactors were under construction: in Finland (Olkiluoto-3) and in France (Flamanville-3) ${ }^{5}$. The remaining blocks under construction are Mochovce-3 and Mochovce-4 in Slovakia (VVER-440/213 type) and Cernavoda-3 and Cernavoda-4 in Romania (CANDU-6 type). Advanced works for preparation build blocks take place in Temelin-3 and 4 (Czech Republic), and Hinkley Point C-1 \& C-2 in the UK, Hinkley Point C-2 (EPR type) in the UK. New nuclear blocks are planned in the Czech Republic, Slovakia, Hungary, France, Bulgaria, Romania, Slovenia, and Poland. Also, Croatia is considering the construction of the nuclear power plant on its own territory (at the moment it has a $50 \%$ stake in the Slovenian Krsko nuclear power plant).

In the EU, we can distinguish among states supporters of the nuclear power (e.g. France, United Kingdom, Czech Republic, Hungary, Slovakia, Romania and Bulgaria) and those that maintain nuclear energy (Sweden), but do not plan new investments in nuclear installations (such as Belgium and Spain) or countries that decided to move away from this source of energy (Germany). The attitude of countries towards the development of the nuclear energy are very diverse, which comes from an influence of various factors including economic (in Europe the nuclear industry creates or supports an estimated 780.000 jobs), environmental, social, political and as well concerns for nuclear safety and security of electricity supplies 6 .

Countries that do not have nuclear power and do not plan to install it include Austria (it buys electricity from nuclear power plants in the Czech Republic, Slovakia, Germany, and Switzerland), Denmark (it buys electricity from nuclear power plants in Sweden and Germany), Greece (it buys electricity from a nuclear power plant in Bulgaria), Italy (Italy imports large amounts of energy from the French and Swiss nuclear power plants, Italian nuclear energy program was terminated after the Chernobyl explosion and the national referendum November 1987), Ireland (imports electricity from British nuclear power plants), Portugal (imports electricity from the Spanish nuclear power plants ), Cyprus and Malta $^{7}$.

Initiation of the cooperation in the civilian nuclear energy sector at the European level has begun with the establishment under The Treaty establishing the European Atomic Energy Community (1957) by six countries (Belgium, France, Germany, Italy, Luxembourg and the Netherlands). In contrast to the European Community, the Euratom did not merge with the EU and retains its separate legal identity. The aim of the organization is a peaceful cooperation in the development of the nuclear technology, research and radiation safety standards among the Member States. A special function is performed by the Euratom Supply Agency (set up in 1960), which implements EU's policies related to supplies of nuclear materials, and is a party to purchase contracts and performs functions in nuclear energy research and development. In the EU uranium ore is mined in small quantities and con-

\footnotetext{
${ }^{5}$ Both projects are significantly delayed in time and significantly exceeded the originally planned budgets.

${ }^{6}$ Europe - Wide Jobs Map, Foratom, http://foratom.org/public/topical-publications/8649-europewide-jobs-map/file.html (access: 6.05.2016); T. Motowidlak, Energetyka jądrowa w Unii Europejskiej, „Polityka Energetyczna”, t. 12, z. 2/1, 2009, s. 37-55.

7 Energetyka jądrowa w Unii Europejskiej, Narodowe Centrum Badań Jądrowych, 22.12.2013, http://www.atom.edu.pl/index.php/component/content/article/59-ej-w-unii-europejskiej/74-energetyka-jadrowa-w-unii-europejskiej.html (access: 2.05.2016).
} 
sumed for domestic needs, therefore imports of primary uranium are almost $100 \%$ of needs. The main sources of uranium supplies are (2014) Kazakhstan (27\%), Canada (17\%), Russia $(18 \%)$, Niger $(15 \%)$ and Australia $(13.5 \%)^{8}$.

Table 1. Existing and planned nuclear reactors in the EU

\begin{tabular}{|c|c|c|c|c|c|c|c|c|c|c|}
\hline \multirow[t]{2}{*}{ Country } & \multicolumn{2}{|c|}{$\begin{array}{l}2015 \text { nuclear } \\
\text { generation }\end{array}$} & \multicolumn{2}{|c|}{$\begin{array}{l}\text { Reactors operable } \\
\text { at March } 2017\end{array}$} & \multicolumn{2}{|c|}{$\begin{array}{c}\text { Reactors under } \\
\text { construction } \\
\text { at March } 2017\end{array}$} & \multicolumn{2}{|c|}{$\begin{array}{l}\text { Reactors planned } \\
\text { at March } 2017\end{array}$} & \multicolumn{2}{|c|}{$\begin{array}{l}\text { Reactors proposed } \\
\text { at March } 2017\end{array}$} \\
\hline & TWh & $\% \mathrm{e}$ & No. & MWe net & No. & MWe gross & No. & $\begin{array}{l}\text { MWe } \\
\text { gross }\end{array}$ & No. & $\begin{array}{l}\text { MWe } \\
\text { gross }\end{array}$ \\
\hline Belgium & 24.8 & 37.5 & 7 & 5943 & 0 & 0 & 0 & 0 & 0 & 0 \\
\hline Bulgaria & 14.7 & 31.3 & 2 & 1926 & 0 & 0 & 0 & 0 & 1 & 1200 \\
\hline $\begin{array}{l}\text { Czech } \\
\text { Rep. }\end{array}$ & 25.3 & 32.5 & 6 & 3904 & 0 & 0 & 2 & 2400 & 1 & 1200 \\
\hline Finland & 22.3 & 33.7 & 4 & 2764 & 1 & 1700 & 1 & 1200 & 0 & 0 \\
\hline France & 419.0 & 76.3 & 58 & 63,130 & 1 & 1750 & 0 & 0 & $0 ? 1 ?$ & $1750 ?$ \\
\hline Germany & 86.8 & 14.1 & 8 & 10,728 & 0 & 0 & 0 & 0 & 0 & 0 \\
\hline Hungary & 15.0 & 52.7 & 4 & 1889 & 0 & 0 & 2 & 2400 & 0 & 0 \\
\hline Lithuania & 0 & 0 & 0 & 0 & 0 & 0 & 0 & 0 & 2 & 2700 \\
\hline $\begin{array}{l}\text { Nether- } \\
\text { lands }\end{array}$ & 3.9 & 3.7 & 1 & 485 & 0 & 0 & 0 & 0 & 0 & 0 \\
\hline Poland & 0 & 0 & 0 & 0 & 0 & 0 & 6 & 6000 & 0 & 0 \\
\hline Romania & 10.7 & 17.3 & 2 & 1310 & 0 & 0 & 2 & 1440 & 0 & 0 \\
\hline Slovakia & 14.1 & 55.9 & 4 & 1816 & 2 & 942 & 0 & 0 & 1 & 1200 \\
\hline Slovenia & 5.4 & 38.0 & 1 & 696 & 0 & 0 & 0 & 0 & 1 & 1000 \\
\hline Spain & 54.8 & 20.3 & 7 & 7121 & 0 & 0 & 0 & 0 & 0 & 0 \\
\hline Sweden & 54.5 & 34.3 & 9 & 8849 & 0 & 0 & 0 & 0 & 0 & 0 \\
\hline UK & 63.9 & 18.9 & 15 & 8883 & 0 & 0 & 11 & 15,605 & 2 & 2300 \\
\hline $\mathbf{E U}$ & 815.2 & c27\% & 128 & 119,421 & 4 & 4392 & 24 & 29,045 & 8 or 9 & 9600 \\
\hline
\end{tabular}

Source: World Nuclear Power Reactors \& Uranium Requirements, WNA May 2017, http://www.world-nuclear.org/information-library/country-profiles/others/european-union.aspx (access: 3.06.2017).

European nuclear industry covers all phases of the fuel cycle from uranium conversion (before enrichment) to the processing of the spent fuel, yet energy companies based on the principle of the free market, order various services in the field of conversion, enrichment and fuel production also outside of the EU. Uranium conversion is conducted in Comurhex plants in France (part of the group AREVA group), Springfields Fuels Ltd in the UK, NUKEM in Germany, and relatively small production capacity plant in Pitesti, Romania processing uranium for use the CANDU type reactors ${ }^{9}$. Uranium enrichment is completed in French plant Georges Besse II, and English-Dutch-German Urenco plants in Capenhurst,

${ }^{8}$ Nuclear Power in the European Union, World Nuclear Association, May 2016, http://www.worldnuclear.org/information-library/country-profiles/others/european-union.aspx (access: 5.05.2016).

${ }_{9}$ Do 2010 roku istniał brytyjski BNFL (British Nuclear Fuels Limited) w Sellafield dokonujący konwersji uranu. 
Almelo, and Gronau (they provide approx. $70 \%$ of services in the EU) ${ }^{10}$. French Cogema La Hague plant deals with the whole process of production and processing of nuclear fuel including the recovery of uranium from spent fuel.

In the European Union, in particular, the Western Europe, there is a significant degree of interconnections of electricity transmission network (European electricity transmission infrastructure is $70 \%$ based in North - Western and South Europe - ranging from Portugal to Finland). It is expected that the electricity markets in the Czech Republic, Slovakia, Hungary, and Romania will soon be integrated with the rest of Europe. Poland is partially connected with the of the north-western region through the underwater line to Sweden. The possibility of integration of Italy depends on the success of the EU - Swiss negotiations regarding the connection of their power systems. The completion of the single energy market (IEM, internal energy market), including the electricity market, is the key to reliable electricity supplies in the pan-European dimension, including usage of that generated in nuclear power plants.

The EU has some of the most advanced legal and technical standards of nuclear safety in the world, which is an absolute priority for the European Commission. Following the accident at the Fukushima Daiichi nuclear safety standards were tightened even more especially in the control of radioactive waste and spent nuclear fuel and radiation protection, and also a comprehensive risk assessment (stress tests) of nuclear reactors were introduced.

\section{TOPOGRAPHY OF NUCLEAR ENERGY IN THE EU MEMBER STATES PROPONENTS OF NUCLEAR ENERGY}

France has the most developed nuclear programme, which makes them the world leader in building reactors, their servicing, and processing nuclear fuel. After the United States, France is placed second in term of the number of civilian nuclear reactors ( 58 reactors in 19 power plants operated by Electricité de France, EDF), and is the world's largest producer of energy in nuclear power plants in per capita terms, as well as the second, again after USA, in the total installed capacity (and the largest in the EU). Power plants are spread throughout the French territory, especially near large rivers or on the coast. Nuclear energy covers ca. $40 \%$ of the total energy consumption of the country, and has $76 \%$ share in electricity production (2014). Production and export of electricity is an important pillar of French economy conducive to offsetting the trade balance and job creation (estimated at $410,000$ in the direct and indirect sectors $)^{11}$. France is also one of the few countries in the world to reprocess spent nuclear fuel at the plant COGEMA in La Hague. French gained their experience in nuclear power during the research done on the military use of nuclear energy, and the oil crisis of 1973 caused the French government of Pierre Messmer to launch the industrial programme of nuclear power development on 6th March 1974, which aimed

${ }^{10}$ Tricastin : l'usine d'enrichissement Georges Besse II, http://www.areva.com/FR/activites-887/sitedu-tricastin-l-usine-d-enrichissement-georges-besse-ii.html (access: 5.05.2016). The plant is based on an Eurodif consortium, which operated in the period 1978-2012. France (via SET company) is currently expanding its production capacity in this area, building in a joint venture project with Urenco, a new Tricastin enrichment plant Georges Besse II, planned to reach a full production capacity in 2018.

11 T. Młynarski, Francja w procesie uwspólnotowienia bezpieczeństwa energetycznego i polityki klimatycznej Unii Europejskiej, Kraków 2013, s. 65. 
to make power production independent from external resources. This changed the energy situation of France, and the 1970s passed under the slogan "all-electric, all-nuclear" (tout électrique-tout nucléaire). President François Hollande announced the reduction nuclear energy in the mix from 75 to $50 \%$ in the energy balance of the country, although the main motive for this decision was the poor technical condition of the nuclear facilities, as almost half of the reactors within the next decade would enter the end of their operational term, which prevented a rather sudden shift from the technology at nearby future ${ }^{12}$.
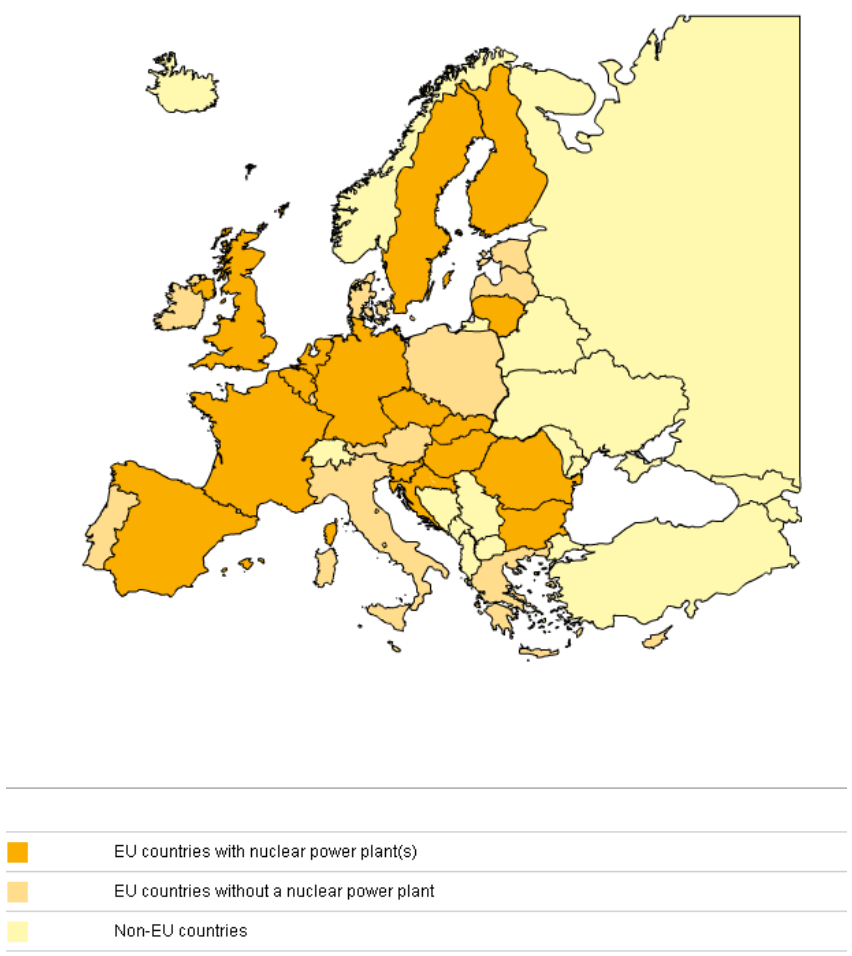

Fig. 1. Nuclear energy in Europe

Source: Nuclear energy in the EU, European Nuclear Safety Regulators Group (ENSREG, http://www.ensreg.eu/members-glance/nuclear-eu.

A country which is currently planning the construction and intensive development of new nuclear power plants is the United Kingdom. In the first half of 2015, UK had 16 blocks working, producing over $17 \%$ of the electric power generated in the entire country. In the 1950s the power capabilities of the country were mostly based on coal - its share in electricity generation amounted to $99 \%^{13}$. As a departure from coal was apparent, mainly due to the increasing costs of mining but also have the negative impact on the environment, it was decided to develop nuclear energy. The first power plant unit was launched in 1956 in

${ }^{12}$ Even as a presidential candidate, François Hollande declared the closure of 24 from the 58 reactors.

${ }^{13}$ G. Jezierski, Energia jądrowa wczoraj i dziś, Warszawa 2005, s. 463. 
Calder Hall, and the next respectively one, two, and three years later. All nuclear power plants have been located on the seashore, as the condensate cooling system used seawater. British Energy is one of the largest producers of electricity in the UK. The British nuclear industry is self-sufficient in terms of conversion, enrichment, fuel production, processing, and disposal of waste. UK has all the facilities needed for the fuel cycle including processing plants. Britain as one of the few countries in the world who has both uranium enrichment plant at Capenhurst which uses centrifuge technology, and is included in the international URENCO consortium, as well as a plant producing uranium-plutonium MOX fuel plant at Sellafield ${ }^{14}$. Almost all the British civilian nuclear power facilities need to be replaced by 2023, however, the British government, in a document entitled The UK's Nuclear Future, states that nuclear energy will play a significant role in the energy mix, and the government will present its plans to adapt the nuclear industry in order for it to play a leading manufacturing role ${ }^{15}$. United Kingdom is planning to acquire about $16 \mathrm{GW}$ of power from nuclear energy. Some of the reactors are operated by EDF Energywhich has obtained permission to build two new reactors atHinkley Point $\mathrm{C}$ (there are plans to construct four new reactors until 2030).

Nuclear power is under development also in Finland, whereas of 2015 there werefour nuclear units (delivering $34.6 \%$ of the electricity demand), and two more were under construction. The construction of the reactor in Olkiluoto was a part of the government's strategy to achieve the objective of a zero percent increase in emissions in comparison to 1990 under the Kyoto Protocol. No power from the OL3 unit forced Finland to use the ETS instrument to compensate for the greenhouse gases emitted in the country.

In Central-Eastern Europe, since 1950s, nuclear power has been developed on the basis of Soviet engineering solutions, and with the support of Soviet technicians. As a result, Slovakia operates four nuclear reactors, which produce more than half of the country's electricity (56.8\%). In 1958, the Czechoslovak government first began construction of a nuclear power plant in Bohunice (now Slovakia), completed in 1972. Additional WWER-440 V-230 units supplied by Atomenergoexport were connected to the network in 1978 and 1980 (V-1 plant), and Mochovce-1 and Mochovce-2 plants were launched successively in 1998 and 1989. In 1995 the government approved a plan to complete Mochovce-3 and Mochovce-4 reactors, commissioned for 2017-18. There are six Russian-designed reactors functioning in the Czech Republic at two power plants, Dukovany and Temelín (four WWERs 440-213 and two WWERs 1000-320). They produce 36\% of electricity (2014) for the Czech Republic. In 1978 the construction of the Dukovany power plant began - the first nuclear power plant in the present Czech Republic (WWERs-440 V-213 were designed by Russian Energoprojekt, and built by Skoda Praha). They went into commercial operation in the years 1985-1987. In 1982 the construction of the plant in Temelin started. Temelin reactors began operation in 2000 and 2002 with the financial assistance of the Export-Import Bank of the United States, and technology supplied by Westinghouse. Czechs plan to increase the share of nuclear energy in the energy balance of their country in view of 2040, so that it becomes the main source of electricity production with a share of $58 \%$.

14 Ibidem, s. 466-467.

${ }^{15}$ The UK's Nuclear Future, Industrial strategy: government and industry in partnership, HM Government, https://www.gov.uk/government/uploads/system/uploads/attachment_data/file/ 168048/bis-13-627-nuclear-industrial-strategy-the-uks-nuclear-future.pdf (access: 5.05.2016). 
There is only one nuclear power plant in Hungary, situated in Paks. It has four WWERs 440-213, and provides more than half of the electricity for domestic consumption (2014) ${ }^{16}$. The units were completed in the 1970s and 1980s as a result of interstate agreements with the Soviet Union, so the four units in Paks will have reached the end of their operation in 2012-2017. In November 2005 the Hungarian Parliament decided to extend the operation of the plant by another 20 years, for all four reactors (in 2030 they will have been working for 50 years) ${ }^{17}$. Additionally, in March 2009, the Hungarian parliament approved the construction of two additional reactors at Paks, which costs will be covered in $80 \%$ by a loan granted by Russia.

Romania uses nuclear technology to produce power, which amounts to almost $20 \%$ of electricity ${ }^{18}$. The first commercial nuclear power plant reactor in Romania was established in 1996, and a second one in May 2007. 32\% of the electricity produced in Bulgaria is provided by two blocks of the Kozloduy power plant located $200 \mathrm{~km}$ Northwest of Sofia. The first commercial nuclear power plant reactor in Bulgaria became operational in 1974. Four of the six reactors was closed as a result of the EU accession agreement. The other two WWERs 1000 now have a license until 2017 and 2021 but the operator picked up efforts to prolong their activity from the current 30 to 50 years (it is possible to achieve a 10-year extension). The Bulgarian government strongly supports the development of nuclear energy, although financial issues constitute a significant limitation.

\section{COUNTRIES DEPARTING FROM NUCLEAR ENERGY, OR MAINTAINING ITS SHARE IN THE ENERGY MIX}

Resignation from nuclear power is not an easy thing, which is showcased by Sweden, which 25 years ago decided to phase out nuclear power. As a result of the referendum in 1980 , the nuclear programme would be ended by 2010. However, in 1994, the government set up a commission, which submitted a report containing a statement that a complete elimination of nuclear energy by 2010 would be economically and ecologically impossible. In June 2010, the Swedish parliament decided (by two votes) to maintain its nuclear programme but new power plants might only be built, subject to the closing of the existing ones $^{19}$. The country has ten operating nuclear blocks, which provide approx. $40 \%$ of domestic electricity $(2014)^{20}$.

Belgium and Spain are the countries who kept nuclear energy but without any plans for new investments. In the first one, nuclear power provides about half the electricity. In 2003, the Belgian Parliament passed a law prohibiting the construction of new reactors and shortening the life of currently working to 40 years, which meant in the case of changes in the energy policy, nuclear power plants will be shut down by 2025 .

\footnotetext{
${ }^{16}$ Nuclear Power in Hungary, WNA, November 2015, http://www.world-nuclear.org/info/CountryProfiles/Countries-G-N/Hungary (25.04.2016).

17 Nuclear Power in Hungary...,

${ }^{18}$ Nuclear Power in Romania, WNA, January 2016, http://www.world-nuclear.org/information-library/country-profiles/countries-o-s/romania.aspx (access: 23.04.2016).

${ }^{19}$ M. Schneider, A. Froggatt, The World Nuclear..., s. 130.

${ }^{20}$ Nuclear Power in Sweden, March 2016, http://www.world-nuclear.org/information-library/country-profiles/countries-o-s/sweden.aspx (25.04.2016).
} 
Spain maintains seven reactors, although the country's moratorium on new plants announced by the government of Prime Minister Jose Luis Zapatero in April 2004, assuming a gradual withdrawal from nuclear energy for growth financing of the development of renewable energy sources. In 2011, the government has restricted the life of nuclear plants to 40 years, which means keeping nuclear power facilities until 2021. The future of nuclear energy in Spain is uncertain but the role of this source of energy was strengthened as a result of consistent high cost of subsidizing the development of renewable energy sources.

Among countries maintaining nuclear energy in the domestic energy balance without plans for its intensive development you can find Netherlands (one reactor at the power plant in Borssele received permission to operate to 2033), and Slovenia (37\% of electricity demand), where there are plans to extend the life of the reactor built in 1981 to 2043.

An example of an EU Member State where anti-nuclear sentiments are very strong is Germany. Their main source of electricity is coal although renewable energy (wind, water, biomass, photovoltaics) is up $26 \%$, while nuclear power provides only $15 \%$ (the same as much as wind and solar power $-14.8 \%$ in 2014.). Nuclear energy is planned to eventually be replaced by renewable energy. German support for nuclear energy was very strong after the oil shock of 1974. The popularity of the idea of environmental responsibility propagated by numerous NGOs and the Green Party, as well as the resulting aversion to nuclear power, has grown in Germany since the early $1970 \mathrm{~s}^{21}$. After the German reunification in 1990, all reactors designed by Soviet engineers were closed and dismantled for safety reasons, and the disaster at Fukushima-Daiichi accelerated the decision on the temporary closure of seven of the seventeen oldest active reactors (built before 1980). The government's decision to decommission all the reactors by 2022 was a response to the public concern and demonstrations against nuclear power in Germany. Germany entered the path of energy transition (Energiewende), becoming one of the biggest promoters of climate protection policy and the development of green technology but at the same time, transforming from an exporter to a net importer of electricity (using nuclear power plants in France, Belgium, the Netherlands, Switzerland, and the Czech Republic ).

\section{NUCLEAR ENERGY AND THE FIGHT AGAINST CLIMATE CHANGE IN THE EU}

Air pollution is a major environmental problem generated largely by the energy sector, hence, the global climate change reinforces the perspective of the development of nuclear power as a carbon-free energy source. There is a close link between greenhouse gas emissions (GHG) emissions and combatting climate change, as energy production is one of the most environmentally damaging industries. Given the growing demand for energy, the reduction of emissions from the energy sector will be crucial to mitigate the effects of global warming. Climate changes force to re-evaluate the current model of the global energy system, based on intensive use of fossil fuels, and transform it into a low-carbon economy, which promotes the popularization of nuclear energy, as a non-carbon power source.

The priorities of EU energy policy are: supply security (diversification) and decarbonisation of energy production. In view of the fact that $27 \%$ of the EU's electricity comes from nuclear power, and further $27 \%$ from renewable sources, the EU generates more than half

${ }^{21}$ R. Bajczuk, Odnawialne źródta energii w Niemczech obecny stan rozwoju, grupy interesu $i$ wyzwania, Raport OSW, Warszawa 2014, s. 12. 
its electricity with no greenhouse gas emissions. Nuclear energy is thus a proven source of low-carbon electricity and has an important role to play in achieving the goals of the climate and energy policy framework by 2030 . The European potential for nuclear power to avoid emission ranges between 700 million tonnes of $\mathrm{CO}_{2}$ - if the share of nuclear were to be replaced by the current energy mix and 300 million tonnes of $\mathrm{CO}_{2}$ if nuclear power were to be replaced by gas $^{22}$.

The European Union is the leader in stopping climate change, and openly aspires to play the leadership role worldwide in this regard (the so-called "climate leadership"). The ambitious climate policy results in establishing very restrictive thresholds for the reduction of GHG emissions. The flagship instrument of the EU which obliged the Member States to adapt energy policy to the standards of low-carbon economy was the Climate \&Energy Package adopted in 2008, which set a goal of reducing GHG emissions by at least $20 \%$ compared to 1990, and increased the share of energy produced from RES (from $8.5 \%$ ) up to $20 \%$ of total energy consumption in the $\mathrm{EU}^{23}$. The new reduction thresholds were adopted at the European Council on $23^{\text {rd }}-24^{\text {th }}$ October 2014. The document established a new threshold limit for GHG emissions in the EU by 2030 at a $43 \%$ reduction to 1990 in sectors covered by the EU Emission Trading System (ETS), and planned increasing the share of renewables by $27 \%$ across the EU (not the Member States), at the same setting an objective to improve energy efficiency by $2030^{24}$. Adopting new reduction restriction meant, in fact, the EU had started walking the path defined by the Energy Roadmap 2050 from March 2011, which assumes the decarbonisation of the electricity sector (reduction of $\mathrm{CO}_{2}$ of ca. 96-99\% in comparison to 1990$)^{25}$. The EU promotes creating the economy with low coal consumption (low-carbon economy), narrowing the climate policy goals of reducing emissions of $\mathrm{CO}_{2}$ to cut back consumption of coal as an energy source. In practice, two noncarbon sources of electricity generation are preferred: renewable and nuclear energy, which consequently opens broad prospects for at least maintaining the significant role of nuclear energy in the EU's energy balance.

${ }^{22}$ Ch. Egenhofer, G. Still, N. Fujiwara, Making the most of the G8+5 Climate Change Process: Accelerating Structural Change and Technology Diffusion on a Global Scale, Centre For European Policy Studies, Brussels 2008, s. 37.

${ }^{23}$ Directive 2009/29/EC of the European Parliament and of the Council to improve and extend the greenhouse gas emission allowance trading scheme of the Community; Decision No 406/2009/EC of the European Parliament and of the Council of 23 April 2009 on the effort of Member States to reduce their greenhouse gas emissions to meet the Community's greenhouse gas emission reduction commitments up to 2020; Directive 2009/31/EC of the European Parliament and of the Council of 23 April 2009 on the geological storage of carbon dioxide; Directive 2009/28/EC of the European Parliament and of the Council on the promotion of the use of energy from renewable sources; Commission Decision of 24 December 2009 determining a list of sectors and subsectors which are deemed to be exposed to a significant risk of carbon leakage.

${ }^{24}$ Conclusions on 2030 Climate and Energy Policy Framework, European Council 23-24 October 2014, Brussels, 23 October 2014, SN 79/14. The main policy instrument to tackle climate change in the EU has become the European Emissions Trading System (EU ETS), establishing emission limits at the level of companies, requiring them to buy permits to emit carbon dioxide within the arbitrarily set the limits of available emission allowances.

${ }^{25}$ Energy Roadmap 2050, European Commission Staff Working Paper 2011.The document is considering, among others, scenario of $15 \%-20 \%$ share of electricity produced by nuclear energy in the middle of the XXI century. 
In October 2007, the European Parliament supported the development of nuclear energy as a necessary option for the EU energy ${ }^{26}$. Despite the fact the European Commission officially maintains a neutral stance towards nuclear power, in May 2008, the President of the EC at that time, José Manuel Barroso, speaking at the European Nuclear Forum in Prague, said that "nuclear energy can make a significant contribution to this battle against climate change" 27 . Barroso also recalled that energy from nuclear fission reactions has become one of the cheapest forms of energy production, and could prevent the European market from the devastating effects of fluctuations in oil prices. According to the EC, decarbonisation of the economy (by increasing the use of renewable energy sources and nuclear energy) will be a recipe for becoming independent from energy imports and diversifying the energy mix. Decarbonisation of the economy has become one of the main objectives of A Framework Strategy for a Resilient Energy Union with a Forward-Looking Climate Change Policy adopted by the EC in February $2015^{28}$. In this document, the EC notes that the transition to a low carbon economy offers great opportunities in terms of growth and employment. "New business sectors, new business models, and new job profiles will emerge. Technological leadership must be followed by the development of industrial production capabilities or technology supply chains across Europe" 29 .

States supporting the development of nuclear power in March 2013 (United Kingdom, Bulgaria, Czech Republic, Finland, France, Hungary, Lithuania, Netherlands, Poland, Romania, Slovakia, and Spain) have joined forces to promote the importance of this source of energy in the EU's energy balance. In a joint ministerial statement on nuclear energy in Europe, they expressed the belief that nuclear energy can play an important role in the future energy mix with low carbon dioxide emissions in the EU, expressing the desire to continue with the implementation of low-carbon technologies ${ }^{30}$. The group of countries supporting nuclear power will, however, shrink after Brexit, as it will change the balance of nuclear policies in the EU, because Germany and other states (Belgium, Spain, Italy) had taken steps in recent years to reduce their reliance on atomic power ${ }^{31}$. The UK's exit from EU

${ }^{26}$ Rezolucja Parlamentu Europejskiego (2007 / 2091 (INI) z 24 października 2007 roku o źródłach energii konwencjonalnej oraz technologiach energetycznych, Parlament Europejski, http://www. europarl.europa.eu/sides/getDoc.do?pubRef=-//EP//TEXT+TA+20071024+ITEMS+DOC+ XML+V0//PL\#sdocta23 (access: 30.04.2016).

27 J.M. Barroso, European Nuclear Energy Forum, Prague, 22.05.2008, SPEECH/08/259, Press Release, http://europa.eu/rapid/press-release_SPEECH-08-259_en.htm (access: 30.04.2016).

${ }_{28}$ Strategia ramowa na rzecz stabilnej unii energetycznej opartej na przysztościowej, Bruksela, 25.02.2015 r.

COM(2015) 80 final, http://eur-lex.europa.eu/resource.html?uri=cellar:1bd46c90-bdd4-11e4bbe1-01aa75ed71a1.0007.02/DOC_1\&format=PDF (access: 30.04 .2016 ).

${ }^{29}$ Ibidem, s. 19.

30 Joint Ministerial Communiqué on Nuclear Energy in Europe, London, 12th March, 2013, https://www.gov.uk/government/uploads/system/uploads/attachment_data/file/140109/final_EU_Nuclear_Energy_Communiqu_.pdf (access: 8.05.2016).

${ }^{31}$ The UK nuclear industry is critically dependent on European goods and services in the nuclear supply chain. That's why leaving Euratom British nuclear industry becomes less competitive (the UK will increase its own nuclear costs) and will experience further delays in nuclear projects realisation. Brexit will also negatively impact the trading of electricity with the EU energy market. In 2015, UK was the net importer of electricity from France and the Netherlands composing 5.8\% of the total electricity supply to the UK. 
structures also means losing a powerful ally in the fight against global warming, because it can re-open the debate on the European climate goals by 2030, threatening dilution the European ambitions of GHG reduction ${ }^{32}$. For the UK Government nuclear industry has a strategic importance, and for this reason the government "will seek alternative arrangements" allowing to continue civil nuclear cooperation with the $\mathrm{EU}^{33}$.

The policy of subsidizing green energy in many EU countries has caused protest of representatives of the nuclear power sector, who pointed out that this high-tech branch of the national economy, creates an opportunity for domestic companies to be the suppliers of products and services. Consequently, in July 2014, nine EU Member States (plus Slovenia), which have developed civil nuclear power industry, sent a letter to the EC demanding equal opportunities for nuclear energy in regards to other sources of low-carbon energy in the EU, so it can play a greater role in energy security, sustainable development, and the reduction of greenhouse gas emissions. "In our view, nuclear energy, for its physical and economic characteristics, is entitled to be treated as an indigenous source of energy with respect to energy security, having an important social and economic dimension... Nuclear power stations insofar as they are compliant with the highest safety standards, bring significant benefits to EU decarbonization, energy security and economic growth. In this respect, the European leadership in nuclear industry should be preserved... it is important that the market failures and the need to hedge against investment risks are accounted for in order to create the necessary market conditions for investment in new nuclear build projects in Europe. A technology neutral approach creating a level playing field for all low-emission sources is crucial" ${ }^{34}$.Therefore, it is extremely important to create equal conditions for the development of production technologies without GHG emissions.

European institutions are aware that tackling climate change by promoting low-carbon economy must take place in parallel with the harmonization of energy policies subjected to transformation and adjustment of economic policies, and the development of nuclear energy can facilitate breaking the connection between economic growth and increasing emissions. Due to the highly advanced age of European nuclear power facilities, one cannot expect that nuclear technology will be the recipe for total decarbonisation of the EU economy. This would require the development of a nuclear energy programme on a large scale. However, nuclear power can significantly help efforts to reduce greenhouse gas emissions, to support the emancipation of the import of energy resources, stimulate innovation economies of

${ }^{32}$ C. Mathieu, Brexit et énergie : vers un accord perdant-perdant?, IFRI 10 Février 2017, https://www.ifri.org/fr/espace-media/lifri-medias/brexit-energie-vers-un-accord-perdant-perdant (dostęp: 15.02.2017).

33 The UK Government has confirmed that it will withdraw from Euratom, so this would require renewing a number of bilateral cooperation agreements in the field of nuclear energy (including agreements within the Euratom Treaty itself). Current bilateral nuclear cooperation agreements are based on application of the Euratom safeguards regime, in: The United Kingdom's exit from and new partnership with the European Union, https://www.gov.uk/government/uploads/system/uploads/attachment_data/file/589191/The_United_Kingdoms_exit_from_and_partnership_with_ the_EU_Web.pdf (dostęp: 15.05.2017); Brexit and Euratom: No rush to exit?, World Nuclear Association, 20 January 2017, http://www.world-nuclear-news.org/V-Brexit-and-EuratomNo-rush-to-exit-20011701.html (dostęp: 20.01.2017).

${ }^{34}$ Ten nations petition Brussels for nuclear, World Nuclear News, 4.07.2014, http://www.world-nuclear-news.org/NP-Ten-nations-petition-Brussels-for-nuclear-0407141.html (access: 15.04.2016). 
member countries, and act as a link in the transformation of energy before a significant increase in the share of renewables in the EU energy mix.

\section{PROSPECTS FOR NUCLEAR ENERGY IN THE EU}

Nuclear power output grows in all major regions of the world apart from Europe. The European Commission predicts a further decline in production capacity of nuclear power plants in the EU by 2025, taking into account the aging reactors and concurrent decisions of some Member States to discontinue use of the nuclear energy or reduce its share in the energy mix. It is estimated that more than 50 of the 129 reactors currently operating in the EU will be closed by $2025^{35}$, while Germany's decision to terminate its nuclear program and the new French legislation in terms of the energy transformation, will reduce the share of nuclear energy from $75 \%$ to $50 \%$ in electricity production, leading to drastic reduction of the EU's nuclear potential ${ }^{36}$. According to forecasts, this trend will be reversed in 2030, when new reactors are connected to the network. European Commission estimates that by 2050 EU's nuclear power plants generation capacity will rise slightly and remain at a constant level between 95 and 105 GWe (which can occur largely as a result of life extension of existing units). At the same time electricity demand increase is forecasted, therefore, the share of nuclear power plants in its generation in the EU will drop from the current $27 \%$ level to $20 \%{ }^{37}$. Most of the 211 nuclear power plants in the EU was built in the years of 70-80ties of the twentieth century, causing the average age of nuclear reactors around 30 years. With a standard 40 year life of reactors that means that many units will need to be closed soon. It is estimated that by 2030, EU's nuclear power capacities lost as a result of the unit's closure (due to the end of its service life, or for political reasons) will outweigh the newfound capacities of new reactors. Therefore, a decrease of the current nuclear capacity of the EU $(120 \mathrm{GWe})$ is expected.

In order to maintain nuclear power plants generating capacity between 95 and $105 \mathrm{GWe}$ in the EU by 2050 and later further investments over the next 35 years. The energy system transformation in line with the strategy for the Energy Union will require significant investment in new power plants to replace most of the existing production capacity, estimated by the European Commission at $350-450$ billion euro ${ }^{38}$. The total investment in the nuclear

\footnotetext{
35 As of October of 2015, 89 reactors were eventually closed in Europe, but so far only 3 reactors were completely dismantled (all in Germany). European operators of the nuclear power plant estimated that the decommissioning of nuclear power plants and radioactive waste management including disposal in deep geological 2050. You will need to spend 253 billion euros, the European Commission estimated that in the years 2015 to 2050 will be required to invest from 3.2 to 4.2 trillion in energy supply in the EU.

${ }^{36}$ EC puts figure on maintaining nuclear capacity, WNA April 4, 2016, http://www.world-nuclearnews.org/NP-EC-puts-figure-on-maintaining-nuclear-capacity-0404164.html (access: 20.04.2016)

${ }^{37}$ Komunikat Komisji, Przyktadowy program energetyki jądrowej przedstawiony na podstawie art. 40 traktatu Euratom w celu uzyskania opinii Europejskiego Komitetu Ekonomiczno-Społecznego, Bruksela, 4.4.2016 r. $\operatorname{COM}(2016) 177$ final, s. 4, https://ec.europa.eu/transparency/regdoc/rep/1/2016/PL/1-2016-177-PL-F1-1.PDF (access: 25.04.2016).

38 Ibidem, s. 5.
} 
fuel cycle (including lifetime extension of existing units, improving safety and waste disposal processes) in the period 2015-2050 is estimated at 650 to 760 billion euro ${ }^{39}$.

In October 2015, the association of national organizations supporting nuclear power development and the nuclear industry in the EU - FORATOM, proposed the launch of 100 new nuclear reactors between 2025-2045, with a total capacity of $122 \mathrm{GW}$, which would allow to maintain the current nuclear power plants potential in $2050^{40}$. Restoration of 120 GW of nuclear capacity by 2050 means theoretically the construction of approx. 120 units over the next 35 years $^{41}$. That's more than three per a year. Meanwhile, since 2000, only five new blocks have been completed in the EU. Both EU's and the global fleet of nuclear reactors gets older. So far as the world's most probable scenario is stagnation, or replacing closed units by new reactors in order to maintain the share of nuclear energy in the global energy mix at current levels, but in the EU itself it is rather foreseen a regress of nuclear of nuclear power. The future of nuclear energy could be improved by change in its classification within Kioto Protocol Clean Development Mechanism (CDM) thanks to the advantages it poses in reduction of $\mathrm{CO} 2$ emissions for the sake of the environment. So far, however, suppliers of civilian nuclear technology were unsuccessful in lobbying for recognition of nuclear power projects eligible under the CDM. Limited social acceptance in the EU and the lack of strong investment (only four reactors under construction in 2016, see. Tab. 1), caused that European nuclear energy industry only to a limited extent will help achieve energy - climate policy objectives by 2030.

\section{CONCLUSIONS}

Nuclear power plays an important role in ensuring the security of electricity supplies in the EU. It combines ecological and economic attributes, i.e. reduces dependence on fossil fuels and helps to avoid huge amounts emissions of carbon dioxide to the atmosphere per annum. Nuclear energy together with renewable energy supplies across the EU more than half of electricity from carbon free sources. The long-term alternative - allowing the reduction of greenhouse gas emissions are renewable energy sources of energy, however, nuclear power can serve as an intermediate solution in the energy transformation, serving as a quasidomestic energy source to provide competitive electricity prices, with no greenhouse gas emissions.

The different attitude of Member States to the development of nuclear energy is a result of the impact various factors including political-historical, economic, environmental, social ones, and as well connected to issues of nuclear safety and security of electricity supply. The biggest challenge for the EU's nuclear power industry is aging fleet of nuclear reactors. Therefore, if the EU wants to maintain the current potential of nuclear power, Member States must make significant investments in order to balance production capacities that will

\footnotetext{
39 Ibidem, s. 6-7.

${ }^{40}$ FORATOM on PINC: maintaining nuclear's current capacity to reach EU energy goals 2050, October 2, 2015, http://www.foratom.org/newsfeeds/377-foratom-on-pinc-maintaining-nuclear-scurrent-capacity-to-reach-eu-energy-goals-2050.html (access: 8.05.2016); Nuclear Fission, SETIS magazine, No. 7, October 2014, https://setis.ec.europa.eu/system/files/Setis_magazine_07_ 2014_web_version.pdf (access: 8.05.2016).

${ }^{41}$ New nuclear power plants are designed to operate for 60 years so they could produce electricity by the end of the twenty-first century.
} 
be lost due to closure of aging power plants. Another issue are necessary investments in order to extend the life of some reactors, decommissioning activities and challenges of nuclear waste long-term storage.

In the long term perspective to replace nuclear power with renewable energy would be counterproductive, because it would mean to maintain a large share of fossil fuels in the EU's energy balance, which emit a lot of pollutants. Renewable energy sources can not be a substitute for nuclear power, if the EU intends to implement its ambitious climate targets. Renewable energy sources rather will not develop on such a scale to allow at the same time replacement of both: the fleet of nuclear reactors and conventional power plants. Therefore, nuclear power, being based on low-carbon technologies and significantly contributing to the security and diversification of supply should remain an important component of the EU's energy mix in the perspective of 2050 and beyond.

\section{REFERENCES}

[1] Bajczuk R., Odnawialne źródta energii w Niemczech obecny stan rozwoju, grupy interesu $i$ wyzwania, Raport OSW, Warszawa 2014.

[2] Barroso J.M., European Nuclear Energy Forum, Prague, 22.05.2008, SPEECH/08/259, Press Release, http://europa.eu/rapid/press-release_SPEECH-08-259_en.htm (access: 30.04.2016).

[3] $\operatorname{COM(2015)~} 80$ final, http://eur-lex.europa.eu/resource.html?uri=cellar:1bd46c90-bdd411e4-bbe1-01aa75ed71a1.0007.02/DOC_1\&format=PDF (access: 30.04.2016).

[4] Conclusions on 2030 Climate and Energy Policy Framework, European Council 23-24 October 2014, Brussels, 23 October 2014, SN 79/14.

[5] EC puts figure on maintaining nuclear capacity, WNA April 4, 2016, http://www.worldnuclear-news.org/NP-EC-puts-figure-on-maintaining-nuclear-capacity-0404164.html (access: 20.04.2016).

[6] Energetyka jądrowa w Unii Europejskiej, Narodowe Centrum Badań Jądrowych, 22.12.2013, http://www.atom.edu.pl/index.php/component/content/article/59-ej-w-uniieuropejskiej/74-energetyka-jadrowa-w-unii-europejskiej.html (access: 2.05.2016).

[7] Energy Roadmap 2050, European Commission Staff Working Paper 2011.

[8] EU energy in figures, Statistical Pocketbook 2015.

[9] Europe - Wide Jobs Map, Foratom, http://foratom.org/public/topical-publications/8649europe-wide-jobs-map/file.html (access: 6.05.2016).

[10] FORATOM on PINC: maintaining nuclear's current capacity to reach EU energy goals 2050, October 2, 2015, http://www.foratom.org/newsfeeds/377-foratom-on-pinc-maintaining-nuclear-s-current-capacity-to-reach-eu-energy-goals-2050.html (access: 8.05.2016).

[11] Jezierski G., Energia jądrowa wczoraj i dziś, Warszawa 2005.

[12] Joint Ministerial Communiqué on Nuclear Energy in Europe, London, 12th March, 2013 https://www.gov.uk/government/uploads/system/uploads/attachment_data/file/140109/final_EU_Nuclear_Energy_Communiqu_.pdf (access: 8.05.2016).

[13] Komunikat Komisji, Przykładowy program energetyki jądrowej przedstawiony na podstawie art. 40 traktatu Euratom w celu uzyskania opinii Europejskiego Komitetu Ekonomiczno-Społecznego, Bruksela, 4.4.2016 r. COM(2016) 177 final. 
[14] Młynarski T., Francja w procesie uwspólnotowienia bezpieczeństwa energetycznego i polityki klimatycznej Unii Europejskiej, Kraków 2013, s. 65.

[15] Motowidlak T., Energetyka jądrowa w Unii Europejskiej, „Polityka Energetyczna”, t. 12, z. 2/1, 2009.

[16] Nuclear energy statistics, Eurostat 2016, http://ec.europa.eu/eurostat/statistics-explained/ index.php/Nuclear_energy_statistics (access: 2.05.2016).

[17] Nuclear Fission, SETIS magazine, No. 7, October 2014, https://setis.ec.europa.eu/system/ files/Setis_magazine_07_2014_web_version.pdf (access: 8.05.2016).

[18] Nuclear Power in Hungary, WNA, November 2015, http://www.world-nuclear.org/ info/Country-Profiles/Countries-G-N/Hungary (25.04.2016).

[19] Nuclear Power in Romania, WNA, January 2016, http://www.world-nuclear.org/information-library/country-profiles/countries-o-s/romania.aspx (access: 23.04.2016).

[20] Nuclear Power in Sweden, March 2016, http://www.world-nuclear.org/information-library/country-profiles/countries-o-s/sweden.aspx (access: 25.04.2016).

[21] Nuclear Power in the European Union, World Nuclear Association, May 2016, http://www.world-nuclear.org/information-library/country-profiles/others/europeanunion.aspx (access: 5.05.2016).

[22] Rezolucja Parlamentu Europejskiego (2007 / 2091 (INI) z 24 października 2007 roku $o$ źródtach energii konwencjonalnej oraz technologiach energetycznych, Parlament Europejski, http://www.europarl.europa.eu/sides/getDoc.do?pubRef=-//EP//TEXT+TA+ 20071024+ITEMS +DOC+XML+V0//PL\#sdocta23 (access: 30.04.2016).

[23] Schneider M., Froggatt A., The World Nuclear Industry Status Report 2014, Paris, London, Washington, D.C., July 2014.

[24] Strategia ramowa na rzecz stabilnej unii energetycznej opartej na przyszłościowej, Bruksela, 25.02.2015 r.

[25] Ten nations petition Brussels for nuclear, World Nuclear News, 4.07.2014, http://www.world-nuclear-news.org/NP-Ten-nations-petition-Brussels-for-nuclear0407141.html (access: 15.04.2016).

[26] The UK's Nuclear Future, Industrial strategy: government and industry in partnership, HM Government, https://www.gov.uk/government/uploads/system/uploads/attachment_ data/file/168048/bis-13-627-nuclear-industrial-strategy-the-uks-nuclear-future.pdf (access: 5.05.2016).

[27] Tricastin: l'usine d'enrichissement Georges Besse II, http://www.areva.com/FR/activites887/site-du-tricastin-l-usine-d-enrichissement-georges-besse-ii.html (access: 5.05.2016).

\section{ENERGIA JADDROWA I JEJ WKŁAD W BEZPIECZEŃSTWO ENERGETYCZNE I OCHRONĘ KLIMATU UNII EUROPEJSKIEJ}

Energetyka jądrowa odgrywa istotną rolę w zapewnianiu bezpieczeństwa dostaw energii elektrycznej w UE. Łączy atrybuty ekologiczne i ekonomiczne, tj. ogranicza zależność od paliw kopalnych oraz pozwala uniknąć emisji do atmosfery olbrzymich ilości dwutlenku węgla rocznie. Największym wyzwaniem dla unijnego przemysłu energetyki jądrowej jest starzenie się floty reaktorów jądrowych. Dlatego też, jeśli UE chce utrzymać dotychczasowy potencjał energetyki jądrowej, państwa członkowskie muszą podjąć znaczące inwestycje mające na celu zrównoważenie dostaw mocy, które zostaną utracone z zamykanych 
wyeksploatowanych elektrowni. W długoterminowej perspektywie zastąpienie energii jądrowej energią odnawialną byłoby niekorzystne, albowiem oznaczałoby utrzymanie dużego udziału paliw kopalnych w bilansie energetycznym UE.

Słowa kluczowe: energia jądrowa, bezpieczeństwo energetyczno-klimatyczne, Unia Europejska.

DOI: $10.7862 /$ rz.2017.hss.53

Przestano do redakcji: kwiecień 2017 r.

Przyjęto do druku: wrzesień 2017 r. 